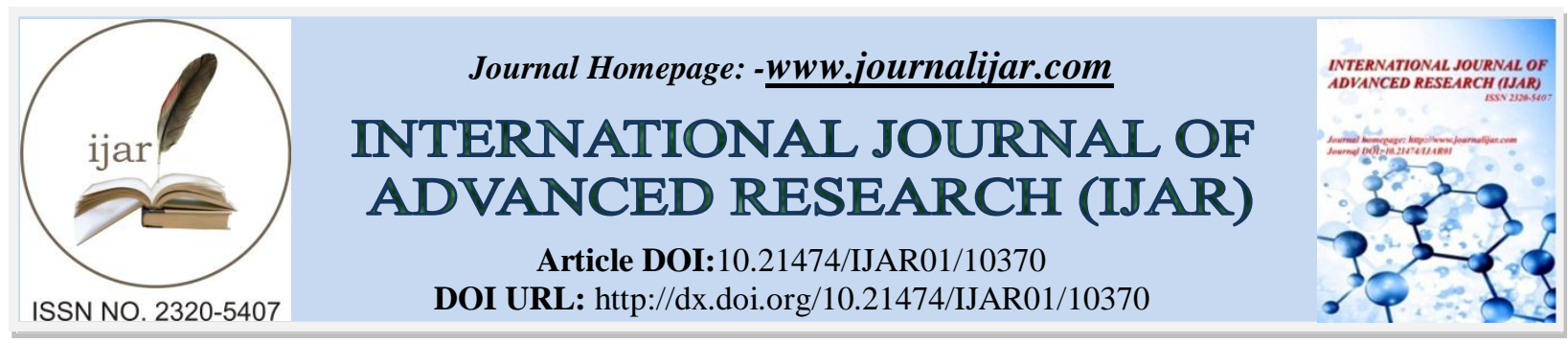

RESEARCH ARTICLE

\title{
FORMS OF VIOLENCE DIRECTED BY HUSBANDS AGAINST THEIR WIVES IN HAIL, KSA
}

Loich Bashir ${ }^{1}$, Harbi Mariam ${ }^{2}$ and Ibrahim Neven ${ }^{3}$

1. Assistant Professor of Department of Social Sciences - Faculty of Arts and Literature, University of Hail, Kingdom of Saudi Arabia.

2. Professor of sociology, University of Hail, Kingdom of Saudi Arabia.

3. Associate Professor of Department of Social Sciences - Faculty of Arts and Literature, University of Hail, Kingdom of Saudi Arabia.

\section{Manuscript Info}

Manuscript History

Received: 30 November 2019

Final Accepted: 31 December 2019

Published: January 2020

\section{Abstract}

The current study aims to define Patterns and sorts of violence Exercised by husbands against their wives in Hail society and It is only about Physical Violence, Psychological Violence, Economic violence and Sexual violence, and unveiling the societal determinants which causes such form of violence The research data were collected from the wives who in hail and defined a comprehensive search of all households living permanently in the village, it was taking a systematic random sample strength where the data were collected by personal interview using a Questionnaire form for this purpose and it collected from the resident women housing provided that they are not divorced or widowed, and if you do not meet the conditions take the next house.

Background: The phenomenon of violence sweeps the world around us in many areas and in most countries of the world without discrimination, but the most dangerous institution that may be plagued by violence from the point of view of researchers is the institution of the family where it is the main unit of the formation of society, and if violence may be directed against the husband or wife or against the children individually or in the community Appointed in due or even as a whole but the violence directed against the wife by her husband is what raised in the same researchers many questions which led them to this study in which they identified three forms of violence directed by the husband against his wife: physical violence, psychological violence, economic violence, in the case of To find out the prevalence of each form of violence as well as to identify some of the factors affecting the forms of violence in question.

Objectives: The current study aims to define Patterns and sorts of violence Exercised by husbands against their wives in Hail city.

Methods: This descriptive study was conducted in Hail, Saudi Arabia. The study included a total of 132 participants from wives who were violently raped by their husbands and who were living in Hail and agreed to participate in the study. Participants were asked about their socio-demographic data, Forms of violence against the Saudi wife residing in Hail in each of the three areas studied (physical violence - 
economic violence - psychological violence). The statistical analysis of data was done by using excel and SPSS version (20). (Chicago, Illinois: SPSS Inc, USA)

Results: The result shows that there are many moral significant correlations between forms of violence (physical violence, economic violence - psychological violence) and some of the variables studied.

Conclusion: In Hail, the present study demonstrated that there was a significant association between physical violence and both the husband's work and the duration of the marriage, and the existence of problems between the spouses. While there is a reverse link between physical violence and both the husband's education and the husband's ambition and the husband's religion. There is also a reverse correlation between economic violence and both the husband's education, the monthly income of the family, the economic level of the family, the ambition of the researched and media openness. and there is correlation between psychological violence and variable number of Children, while there is a reverse correlation between psychological violence and both the economic level of the family, the ambition of the Researched wives. And there is a reverse correlation between psychological violence and the education of the husband.

Copy Right, IJAR, 2020,. All rights reserved.

\section{Introduction:-}

In 1970 domestic violence term was used, referring to acts of violence and abuse against wives, and increased interest in studying this phenomenon during the 1990s, which led to its wider concept to include all acts of violence committed between family members ( Al-Yousef, Al-Rumaih and Niazi, 2005: 5).

The government's policy of promoting the rights of women and girls is a priority for the government.

Saudi Arabia's Tenth Development Plan also included direct directions for strengthening social safety nets, family and child care in Goal 14, with the text: "Supporting programmers to reduce domestic violence and its activities" (Ministry of Economy and Planning, 2016: 14).

Domestic violence is one of the inevitable effects of the nature of modern life, and the changes and transformations it has undergone in all areas, and the family has not been spared from being affected by those changes, which have lost some of its functions, solidarity and unity, having been the first educational institution characterized by cohesion and stability (Al-Faqi, Ahmed and Hajjaj, 1438 Ah: 189).

Domestic violence is a danger to family members, particularly women, who are the beating heart of the family's environment and permanence, and are the most important forms of the family institution.

The theory of patterns has shown that women are an important type of family, and receive from other formats, which makes them a positive influence when those dealings with them positively, and vice versa, and it is natural that the violence directed against them by men will have a clear impact on them first, and on the rest of the patterns Other families (Habib and Hanna, 2016: 236; Al-Nuwahi, 2001: 44).

\section{The Aim of the present study:}

1. Identify the forms of violence against the Saudi wife residing in Hail in each of the three dimensions studied (physical violence - economic violence - psychological violence).

2. Identify the factors affecting the forms of violence against the Saudi wife residing in Hail city in each of the three dimensions studied (physical violence - economic violence - psychological violence).

3. Develop a proposed perception from a social service perspective to deal optimally with battered wives. 


\section{Subjects and Method:-}

\section{Subjects:}

Study setting: this study was carried out in Hail city. The subjects of the present study were wives who were violently raped by their husbands.

\section{Operational Design:}

\section{Pilot study:}

A pilot study was conducted on 20 people living in Hail who represented $15 \%$ of the total sample in order to ensure the clarity of questions, applicability of tools, test their ability to elicit the desired information and the time needed to complete them.

\section{Tools of data collection:}

Tools used in the study were electronic questionnaire and personal interview questionnaire. The questionnaires were previously written by the authors in a simple Arabic language after reviewing literature. The questionnaire included 2 important domains; socioeconomic status, forms of violence against the Saudi wife in each of the three dimensions studied physical violence, economic violence and psychological violence.

Questions about the socioeconomic status included; Age - occupation - marriage period - wife education - wife's education - husband's profession - number of sons - monthly income - problems between spouses - religion of husband - wife's ambition - media openness for the wife. Collection of data was carried out by Researchers, to ensure accuracy of the measurements

\section{Methods (Statistical design):- \\ Research design:}

A descriptive research design was adaptive to fulfill the purpose of the study. It helped the researchers to describe and document the aspects of the pathogenic mechanism as they naturally occur. This design helped to establish a database for further research.

The second part, analytical statistics, is to test statistically significant correlation between the variables, and P-value were used to test association among the variable (8).

The statistical analysis of data was done by using excel and SPSS program version (20). (Chicago, Illinois: SPSS Inc, USA)( ). The first part of the data was descriptive data which were revised, coded, tabulated, and statistically analyzed using the proportion and percentage.

\section{Field work:}

Once officially permission was granted from the research committee, the researchers initiated data collection. The data collection of this study was carried out in period from August2019 to December 2019 in Hail city. Data were collected every day. The researchers met (132) of respondents residing in Hail. The researchers introduced themselves to the respondents who agreed to be included in this study and voluntary consent was taken. Participants were also informed that their responses will be confidential and used for research purposes only. The researchers explained the purpose of the study to each respondent included in the study.

\section{Results:-}

Table I:- physical violence of the studied sample.

\begin{tabular}{|l|l|l|l|l|l|l|l|l|}
\hline \multirow{2}{*}{ Phrase } & \multicolumn{2}{l|}{ It never happens. } & \multicolumn{2}{l|}{ It rarely happens } & \multicolumn{2}{l|}{ It could happen. } & \multicolumn{2}{l|}{$\begin{array}{l}\text { It's } \\
\text { happening. }\end{array}$} \\
\cline { 2 - 9 } & $\begin{array}{l}\text { frequenc } \\
\text { y }\end{array}$ & $\begin{array}{l}\text { percentage } \\
\text { s }\end{array}$ & $\begin{array}{l}\text { frequenc } \\
\text { y }\end{array}$ & $\begin{array}{l}\text { percentage } \\
\text { s }\end{array}$ & $\begin{array}{l}\text { frequenc } \\
\text { y }\end{array}$ & $\begin{array}{l}\text { percentage } \\
\text { s }\end{array}$ & $\begin{array}{l}\text { frequenc } \\
\text { y }\end{array}$ & $\begin{array}{l}\text { percentage } \\
\text { s }\end{array}$ \\
\hline $\begin{array}{l}\text { Pushing } \\
\text { you, or } \\
\text { pulling } \\
\text { your hair }\end{array}$ & 84 & 63.6 & 20 & 15.2 & 24 & 18.2 & 4 & 3 \\
\hline $\begin{array}{l}\text { Beating } \\
\text { you with a }\end{array}$ & 100 & 75.8 & 16 & 12.1 & 12 & 9.1 & 4 & 3 \\
\hline
\end{tabular}




\begin{tabular}{|c|c|c|c|c|c|c|c|c|}
\hline $\begin{array}{l}\text { hand, or } \\
\text { something } \\
\text { else that } \\
\text { would hurt } \\
\text { you. }\end{array}$ & & & & & & & & \\
\hline $\begin{array}{l}\text { Kick you, } \\
\text { drag you, } \\
\text { or beat you } \\
\text { up. }\end{array}$ & 100 & 75.8 & 12 & 9.1 & 16 & 12.1 & 4 & 3 \\
\hline $\begin{array}{l}\text { Trying to } \\
\text { strangle } \\
\text { you, or } \\
\text { burn you } \\
\text { on } \\
\text { purpose. }\end{array}$ & 124 & 93.9 & - & - & 8 & 4 & - & - \\
\hline $\begin{array}{l}\text { Threatenin } \\
\mathrm{g} \text { to use a } \\
\text { gun, knife, } \\
\text { or any } \\
\text { other } \\
\text { weapon. }\end{array}$ & 124 & 93.9 & - & - & 4 & 3 & 4 & 3 \\
\hline $\begin{array}{l}\text { He hit you } \\
\text { during } \\
\text { pregnancy. }\end{array}$ & 120 & 90.9 & 4 & 3 & - & - & 8 & 6.1 \\
\hline $\begin{array}{l}\text { Going to } \\
\text { the hospital } \\
\text { because of } \\
\text { injuries } \\
\text { caused by } \\
\text { your } \\
\text { husband }\end{array}$ & 116 & 87.9 & 4 & 3 & 8 & 6.1 & 4 & 3 \\
\hline
\end{tabular}

Results of the present work in table (1) have indicated that The majority of the respondents answered that no physical violence by the husband, and answered that he is always accounted for a very small proportion compared to whichever parent had answered without happen, this may be due to the culture of the community, who consider that the secrets of the marital relationship and should not be disclosed.

Table II:- Economic violence of the studied sample.

\begin{tabular}{|c|c|c|c|c|c|c|c|c|}
\hline \multirow[t]{2}{*}{ Phrase } & \multicolumn{2}{|c|}{$\begin{array}{l}\text { It never } \\
\text { happens. }\end{array}$} & \multicolumn{2}{|c|}{$\begin{array}{l}\text { It rarely } \\
\text { happens }\end{array}$} & \multicolumn{2}{|c|}{ It could happen. } & \multicolumn{2}{|c|}{$\begin{array}{l}\text { It's always } \\
\text { happening. }\end{array}$} \\
\hline & $\begin{array}{l}\text { frequ } \\
\text { ency }\end{array}$ & $\begin{array}{l}\text { percent } \\
\text { ages }\end{array}$ & $\begin{array}{l}\text { frequ } \\
\text { ency }\end{array}$ & $\begin{array}{l}\text { percent } \\
\text { ages }\end{array}$ & $\begin{array}{l}\text { frequ } \\
\text { ency }\end{array}$ & $\begin{array}{l}\text { percent } \\
\text { ages }\end{array}$ & $\begin{array}{l}\text { freque } \\
\text { ncy }\end{array}$ & $\begin{array}{l}\text { perce } \\
\text { ntage } \\
\mathrm{s}\end{array}$ \\
\hline $\begin{array}{l}\text { Your husband forbids you from } \\
\text { working against your will. }\end{array}$ & 84 & 63.6 & 8 & 6.1 & 24 & 18.2 & 16 & 12.1 \\
\hline $\begin{array}{l}\text { Forces you to participate in } \\
\text { spending on the house. }\end{array}$ & 72 & 54.5 & 4 & 3 & 24 & 18.2 & 32 & 24.2 \\
\hline $\begin{array}{l}\text { It doesn't provide your personal } \\
\text { requirements }\end{array}$ & 48 & 37.4 & 16 & 12.1 & 28 & 21.2 & 40 & 30.3 \\
\hline $\begin{array}{l}\text { He takes your savings against your } \\
\text { will. }\end{array}$ & 88 & 66.7 & 20 & 15.2 & 24 & 18.2 & - & - \\
\hline $\begin{array}{l}\text { He takes money from your account } \\
\text { without your knowledge. }\end{array}$ & 104 & 78.8 & 16 & 12.1 & 12 & 9.1 & - & - \\
\hline $\begin{array}{l}\text { He wants to know all the details of } \\
\text { your spending }\end{array}$ & 52 & 39.4 & 4 & 3 & 28 & 21.2 & 48 & 36.4 \\
\hline
\end{tabular}




\begin{tabular}{|l|l|l|l|l|l|l|l|l|}
\hline $\begin{array}{l}\text { Does not provide the necessary } \\
\text { requirements of the home }\end{array}$ & 60 & 45.5 & 24 & 18.2 & 20 & 15.2 & 28 & 21.2 \\
\hline $\begin{array}{l}\text { He doesn't talk to you about any } \\
\text { financial matters. }\end{array}$ & 28 & 21.2 & 28 & 21.2 & 40 & 30.3 & 36 & 27.3 \\
\hline $\begin{array}{l}\text { You don't know anything about your } \\
\text { husband's monthly income. }\end{array}$ & 44 & 33.3 & 16 & 12.1 & 28 & 21.2 & 44 & 33.3 \\
\hline
\end{tabular}

Results of the present work in table (II) that the most answered phrases of the research that it always happens are (he wants to know all the details of your spending) by a percentage of $36.4 \%$ followed by (does not provide your personal requirements) by a percentage of $30.3 \%$ and then (you know nothing about your husband's monthly income) by $33.3 \%$ and more phrases that do not She spoke (withdraws money from your account without your knowledge) by $78.8 \%$ followed by (taking your savings against your will) by $66.7 \%$; life) and try to withdraw from her income.

Table III:- Psychological violence of the studied sample.

\begin{tabular}{|c|c|c|c|c|c|c|c|c|}
\hline \multirow[t]{2}{*}{ Phrase } & \multicolumn{2}{|c|}{ It never happens. } & \multicolumn{2}{|c|}{ It rarely happens } & \multicolumn{2}{|c|}{ It could happen. } & \multicolumn{2}{|c|}{ It's always happening. } \\
\hline & $\begin{array}{l}\text { frequen } \\
\text { cy }\end{array}$ & $\begin{array}{l}\text { percentag } \\
\text { es }\end{array}$ & $\begin{array}{l}\text { frequen } \\
\text { cy }\end{array}$ & $\begin{array}{l}\text { percentag } \\
\text { es }\end{array}$ & $\begin{array}{l}\text { frequen } \\
\text { cy }\end{array}$ & $\begin{array}{l}\text { percentag } \\
\text { es }\end{array}$ & $\begin{array}{l}\text { frequen } \\
\text { cy }\end{array}$ & $\begin{array}{l}\text { percentag } \\
\text { es }\end{array}$ \\
\hline $\begin{array}{l}\text { He says } \\
\text { insult to you, } \\
\text { which It } \\
\text { makes you } \\
\text { feel } \\
\text { uncomfortab } \\
\text { le about } \\
\text { yourself. }\end{array}$ & 48 & 36.4 & 24 & 18.2 & 32 & 24.2 & 28 & 21.2 \\
\hline $\begin{array}{l}\text { Your } \\
\text { husband } \\
\text { underestimat } \\
\text { es you. }\end{array}$ & 52 & 39.2 & 16 & 12.1 & 28 & 21.1 & 36 & 27.3 \\
\hline $\begin{array}{l}\mathrm{He} \text { insults } \\
\text { you in front } \\
\text { of others. }\end{array}$ & 72 & 54.5 & 16 & 12.1 & 20 & 15.2 & 24 & 18.2 \\
\hline $\begin{array}{l}\text { He's doing } \\
\text { things to } \\
\text { Makes you } \\
\text { feel scared. }\end{array}$ & 56 & 42.4 & 20 & 15.2 & 32 & 24.2 & 24 & 18.2 \\
\hline $\begin{array}{l}\text { He threatens } \\
\text { to harm you } \\
\text { or anyone } \\
\text { close to you. }\end{array}$ & 100 & 75.8 & 16 & 12.1 & 16 & 12.1 & - & - \\
\hline $\begin{array}{l}\text { He ignores } \\
\text { you and } \\
\text { treats you } \\
\text { with } \\
\text { indifference. }\end{array}$ & 56 & 42.4 & 16 & 12.1 & 16 & 12.1 & 44 & 33.3 \\
\hline $\begin{array}{l}\text { He prevents } \\
\text { you from } \\
\text { contacting } \\
\text { your parents. }\end{array}$ & 112 & 84.8 & 12 & 9.1 & 4 & 3 & 4 & 3 \\
\hline $\begin{array}{l}\text { He prevents } \\
\text { you from } \\
\text { seeing your } \\
\text { friends. }\end{array}$ & 68 & 51.5 & 20 & 15.2 & 28 & 21.2 & 16 & 12.1 \\
\hline
\end{tabular}




\begin{tabular}{|l|l|l|l|l|l|l|l|l|}
\hline $\begin{array}{l}\text { He doesn't } \\
\text { care about } \\
\text { your } \\
\text { success. }\end{array}$ & 52 & 39.4 & 8 & 6.1 & 4 & 3 & 68 & 51.5 \\
\hline
\end{tabular}

Results of the present work in table (III) that the most answered phrases that always happen was (not caring for your success) by a percentage of $51.5 \%$ i.e. more than half of the respondents have always answered (ignores and treats you with indifference) by a percentage of $33.3 \%$ or almost one third of the respondents while the most unanswered answers were on the phrases (prevent you Of your contact with your family) $84.8 \%$ followed by (threatens to harm you or any of the people close to you) by $75.8 \%$ and then (preventing you from seeing your friends) by $51.5 \%$, this result is consistent with the results of a number of previous studies contained in the theoretical framework and the researchers explain that this may be due to other factors, including Men's perception of women is that their success is not important for family members, an indicator that may need to be educated.

Table IV:- Averages and percentages of the dimensions of violence in the sample.

\begin{tabular}{|l|l|l|}
\hline Dimensions of violence & Average arithmetic & Standard deviation \\
\hline Physical violence & 10.330 & 5.714 \\
\hline Economic violence & 24.440 & 8.745 \\
\hline Psychological violence & 22.848 & 11.496 \\
\hline
\end{tabular}

Results of the present work in table (IV) that the most common type of violence is economic violence with an average calculation capacity of 24.44 and a standard deviation of 8.7 , followed by psychological violence with a mathematical average of 22,848 with a standard deviation of 11,496 , followed by physical violence with a mathematical average of 10.33 with a standard deviation of 5.714 .

The researchers explain the rise in economic violence, mainly because of the social change that may be burdensome for men in the cost of life, which resulted in his belief that women are obliged to participate in the expenses of life, and this results in the interest in community education towards this The government's policy of "protecting the rights of women" is a matter of concern .

From the results of the current study and the results of previous studies, the results are clearly different, and may be due to the specificity of the culture of Saudi society, and women in particular

Table V:- Correlation between Patterns of violence and different Socio-demographic characteristics of the present study sample.

\begin{tabular}{|c|c|c|c|}
\hline Socio-demographic characteristics & Physical violence & Economic violence & Psychological violence \\
\hline Age & 0.170 & $0.20-$ & 0.135 \\
\hline occupation & $0.197 *$ & 0.76 & $0.209 * *$ \\
\hline marriage period & $0.206^{*}$ & 0.160 & $0.331 * *$ \\
\hline wife education & 0.004 & 0.090 & 0.033 \\
\hline husband's education & $0.376-* *$ & $0.285 * *$ & 0.190 \\
\hline husband's profession & 0.015 & 0.023 & 0.116 \\
\hline Number of sons & 0.120 & 0.009 & $0.176^{*}$ \\
\hline Monthly income & $0.133-$ & $0.02377_{-}^{*} *$ & 0.131 \\
\hline The economic level of the family & 0.158 & $0.401-* *$ & $0.229+* *$ \\
\hline Problems between spouses & $0.429 * *$ & $0.676 * *$ & $0.742 * *$ \\
\hline wife's ambition & $0.506-* *$ & $0.404-* *$ & $0.462 \_* *$ \\
\hline religion of husbands & $0.248-* *$ & 0.537 *** & $0.5544^{*} * *$ \\
\hline Media openness for the wife. & $0.153-$ & $0.180 \_*$ & 0.129 \\
\hline
\end{tabular}

Results of the present work in table (V)that there is a positive direct correlation between physical violence and both the husband's work and the duration of the marriage, where the value of the correlation factor was $0.197,0.206$, which is moral values at 0.05 , while there is a direct correlation at the level of 0.01 between physical violence and the existence of problems between the spouses, where the value of the rate of art Bat 0.429 may be due to the fact that problems generate physical violence between spouses. 
While there is a reverse link between physical violence and both the husband's education and the husband's ambition and the husband's religion, where the values of the correlation transactions are $-0.376,0.506,0.248$, all of which are moral at 0.01 , all of which make sense where the higher the level of education and religiosity of the husband; The high ambition of the wifes makes her do not allow such behavior from the husband, while there is no association between physical violence and other variables.

There is also a reverse correlation at a moral level of 0.01 between economic violence and both the husband's education, the monthly income of the family, the economic level of the family, the ambition of the researched, the husband's debt where the values of the correlation transactions amounted to $0.285,0.237,0.401,0.404,0.537$ respectively, while there is a reverse correlation at the level of 0.05 Between economic violence and media openness, while there is an expulsion link at 0.01 between the economic violence of the husband and the existence of problems with the wife.

There is also a positive expulsion link at 0.01 between psychological violence, both the variables of the work of the research, the duration of the marriage, and the existence of problems between the spouses, where the values of bilateral correlation transactions amounted to $0.209,0.331,0.742$ respectively, while there is a direct correlation at 0.05 between psychological violence and variable number. Children, while there is a reverse correlation at 0.01 between psychological violence and both the economic level of the family, the ambition of the researched, condemns the husband where the values of the correlation transactions amounted to $0.229,0.462,0.554$ while there is a reverse correlation at the level of 0.05 between psychological violence and the education of the husband where the value of the correlation coefficient was $0.229,0.462,0.554$ while there is a reverse correlation at the level of 0.05 between psychological violence and the education of the husband where the value of the correlation coefficient sat at $0.229,0.462,0.554$, while there is a reverse correlation at the level of 0.05 between psychological violence and the education of the husband where the value of the correlation coefficient was $0.229,0.462,0.554$, while there 0.190 .

It is clear that each of the problems between the spouses has a direct relationship with all dimensions of violence, because the problems may lead the husband to use violence with the wife, as well as there is a reverse link between both the wife's ambition and the husband's religion and the three dimensions of violence, and this may be due to the fact that the husband's religion is considered a barrier to non-abuse. The servants of violence with the wife, which is consistent with our Islamic law.

The proposed perception from a social service perspective of optimal dealing with battered wives

The social service profession is an applied humanitarian profession that seeks to address social diseases, and is practiced in various institutions, multiple, with all segments of society, including the category of abuses.

The profession possesses models and methods of professional intervention for the way in which the individual is served, seeks to protect and treat individuals, develop their abilities and potential, as well as to possess models and methods of professional intervention with families and groups; and develop their abilities.

It also possesses models, methods and techniques that are used with segments of society, which seek to invest all resources, work on their development and good exploitation, and employ them to address the problems of society.

The problem of the current study is therefore related to domestic violence, and many scientific models and methods can be used to suit victims of domestic violence, particularly since the problem is complex, complex and overlapping; The problem of violence requires working with clients, including:

1. Working with the turbines.

2. Working with individuals within the family.

3. Working with social institutions in society.

4. Working with the community in general.

In this scenario, we will review the concept and philosophy of the programmed, the theoretical orientations of the proposed programmed, as well as a review of some models, working patterns, methods, techniques and strategies, as well as the stages of professional intervention that the proposed programmed is going through. 


\section{First:}

The concept of a professional intervention programmed with violent women

The concepts of the professional intervention programmed are numerous, but all of them have agreed that: these professional efforts and actions, which can be carried out by a social worker, follow the scientific method, and are based on practice models to optimally deal with victims of domestic violence, especially violent women; Required in customer formats (individual, family, community, institution, community) based on knowledge, skills, and practice values in order to achieve the desired goals.

\section{Second:}

The scientific philosophy on which the program of professional intervention with violent women is based

1. The program is based on the philosophy that violent women may have limited their capacities, and their potential, to address the problem of domestic violence and its effects on its own.

2. Domestic violence has negative effects on violent women, on the family and on society;

3. The social service profession has many different forms of scientific professional practice at the level of individuals, families, groups, institutions and communities, through which the problem can be alleviated.

\section{Third:}

The objectives of the professional intervention program with violent women

1. Work on the design of scientific standards based on the results of the current study and previous studies, in accordance with the culture of Saudi society, to be applied to victims of domestic violence.

2. Work on the design of a training program through which social workers working in the field of domestic violence are provided in accordance with scientific steps.

3. Work to comprehensively rehabilitate victims of domestic violence for social re-adaptation.

4. Work to cooperate with the relevant authorities in carrying out awareness campaigns and educate members of the community about the danger of domestic violence and its negative effects.

\section{Fourth:}

The theoretical guidelines of the program of professional intervention with violent women

There are many interpretive theories of domestic violence, so the social service profession benefits from the facts and vocabulary of the theories in explaining the problem of domestic violence, including the following:

Behavioral theory, ecological theory, functional structural, pattern theory, problem solving theory, needs theory, etc.

Fifth:

Strategies used in the professional intervention program with violent women

1. Behavior change strategy, used to change certain habits and wrong behaviors, such as thinking about suicide, and not being positive.

2. The training strategy against the stress of domestic violence is used to reduce tension, conflict and anxiety experienced by violent women.

3. Confrontation and challenge strategy, used to enable violent women to form will in the face of the circumstances they are going through to get rid of them, to a better situation.

4. A strategy to change attitudes, used to change the negative and wrong thoughts of violent women towards themselves, or others, and to replace them with positive trends that support their adaptation and selfrealignment.

5. The persuasion strategy, which is used to convince violent women, of their abilities, potential and use to reduce the effects of domestic violence.

6. Social support strategy, which means providing self-support and positive reinforcement of violent women both cognitively, materially, morally and skillfully.

\section{Sixth:}

Methods and tools used in the professional intervention program with violent women

There are many methods that can be used in the professional intervention program, depending on the nature of the violent woman and the specificity of the problematic situation she is going through, including:

Individual and group interviews, group discussions, brainstorming, modeling, role-playing, lectures, seminars, and conferences. 


\section{Discussion:-}

The aim of the present study was to Identify the forms of violence against the Saudi wife residing in Hail in each of the three dimensions studied (physical violence - economic violence - psychological violence).and Identify the factors affecting the forms of violence against the Saudi wife residing in Hail city in each of the three dimensions studied (physical violence - economic violence - psychological violence). and Develop a proposed perception from a social service perspective to deal optimally with battered wives. The study was carried out in Hail city on 132 individuals; the present study indicated that the violence directed against the wife by her husband will have a clear impact on her first, and on other family styles this was supported by a study conducted in Habib and Hanna work.

According to the present study results, husband's education had a significant relationship with Physical violence, Economic violence, and Psychological violence And that's consistent with what Badawi's study (2017) found the most important findings: that battered women in Riyadh are subjected to different types of violence, and that less, husband's educated are more likely to experience violence than other educated women husband's.

The results of the current study showed that economic factors such as monthly income, especially the husband's income and the standard of living of the family, It is one of the most important factors causing violence, because the inability of the husband to provide the requirements of life is putting pressure on him that may lead him to violence against the wife. A study conducted by the National Council for Family Affairs (2013) showed that the material factors and difficulties faced by the family are one of the most important causes of violence from the husband, and in the study of Laila Abdul Wahab (1994), Bousboban (2004), The Study of Salma al-Harbi (2005), the Study of Amal Al-Dawa and Zainab Darwish (2005) and the study Conducted by Health Organization (2001) WHO, Yaminshail Study (2010), Chokkanathan Study (2012) and Suzanne Bessioni (2018) all agreed that economic causes, and low economic level, are among the most important factors leading to violence against their wives, while The Al-Hawati study (2001) showed that economic crises, low standard of living and overlapping roles are one of the most important causes of violence by husbands against their wives, as well as amal Bouaisha's study (2015) that poor living, poverty and lack of housing are among the most important causes of husband violence. The results of the current study are in agreement with several studies that dealt with social factors as one of the causes of domestic violence and husband violence against his wife in particular, and many social factors and varied, including education, work, socialization and other factors that may or may not be a direct or non-causal cause. There are many studies that have studied the relationship between some social variables or social factors and the violence of the husband with his wife, including the study of khatib (2005), the study of the National Council for Family Affairs (2013) and the study of Badawi (2017) which agreed to The existence of a relationship between age and the practice of violence against his wife, and that the age groups most vulnerable to violence are the age group of (20 to 35) years, while the study of Salma al-Harbi (2005) showed that there is no relationship between age and violence, as well as the study of Husseinat (2008) showed that there are no differences in violence between the groups Different mirrors.

In the present work, the husband's education was found to be significantly associated with physical violence and the economic and psychological violence and it is the same with several studies where they found a significant correlation between the husband's education, physical violence and psychological violence, as well as the moral correlation between the husband's education and the economic violence of his wife. (R-value=0.190-0.376_0.285) at a moral level $(\mathrm{P}$-value $=<0.005<0.005 ;<0.005)$ in order, and there are studies on the relationship between the educational level and violence against wives, including the study of Amal Al-Dawa and Zainab Darwish (2005), Naseer Study, Fatima Jadallah and Aisha Husseini (2006) and Sibelkalaca, Pinar Dundar (2010), Yaminshail Study (2010) and Chokkanathan Study (2012) Study of the National Council for Family Affairs (2013) previous studies have agreed that the educational level has an inverse relationship with violence directed by the husband to the wife.

There are studies on women's work and the impact on violence experienced by husbands, including the study of alMuhaymid (2008), Hashimi, Kkhurshd,Hassan (2007), Abeer Al-Sabban (2010), The Gado Study (M2015), the National Council for Family Affairs (2013) and the Al-Khatib Study (2007) Fatima Gad and Aisha Husseini (2006) and Amal Bou Aisha (2015) have agreed that non-working women are more vulnerable to violence than working women.

There are studies on social factors affecting violence, including a WHO study (2001), which showed that the social level has an impact on violence directed by spouses, as well as the study of Yamen Suhail (2010) and faweet (1994) 
all of which proved to be a relationship. Between the social level and the violence of husbands a http://www.journalijar.com/contact-us/ gainst their wives.

Cultural factors affect the violence between couples in a big way, especially with the spread of modern social media, and the spread of the Internet among all age groups and society, which affects social relations between individuals, especially married couples, the husband or wife busy with the Internet for several hours One day and cultural openness to other communities and the spread of social media programs may be an important cause of the spread of many strange habits on our societies, as well as may be a direct or indirect cause of the spread of violence, especially between spouses, some studies have addressed these factors to study Its impact on violence, including the study of Nadia Al-Hayasat (2016), which attributed the reason for the husband's violence because of his preoccupation with social networking sites, and the study of Laila Abdul Wahab (1994), which showed that there is a relationship between husband violence and the low cultural level of husband and wife, and in the study of Kaabi (2013) the results showed that The reasons for spousal violence are watching violent movies.

Personality traits are characteristic of a person, they vary from person to person and some individuals may accept certain attributes that may not be accepted by the other person and there may be negative features leading to violence between spouses, such as dependency, nervousness, stubbornness, jealousy, control, reduced religiosity and other features. There are some studies that have touched on personal ity and its relationship to violence between spouses, including the study of the National Council for Family Affairs (2013), which showed that excess nervousness, ignorance, mental illness, inaction, adolescence, Jealousy, dependency, intolerance is one of the factors that lead to violence between spouses, and in a study of the World Health Organization (2005) showed that one of the causes of violence is the use of drugs and alcohol by the husband, and the low level of self-esteem of both the aggressor and the victim.

Husband-to-wife violence can be divided into four forms: economic violence, physical violence, psychological violence, and sexual violence. One of the studies is to study the forms of violence to which a wife can be exposed and we will review some of these studies, namely:

Nadia Al-Hayasat Study (2016), which showed that the most widespread form of violence between wives is physical violence followed by psychological violence, and i agree with him that physical violence is the most widespread form of studies of Laila Abdul Wahab (1994), the Study of the National Council for Family Affairs (2013) and the Study of Khatib (2005). The Sibel Kalaca \&Pinar Dundar study (2010) and Amal Abu Aisha (2015) showed that violence is physical and psychological and sexual.

While the study of Ahmed Zayed (2002) showed that verbal violence is more widespread, and a study of Suzanne Bessioni (2018) concluded that the most common form of violence is verbal violence, followed by psychological and physical violence, while the study of resin (2008) stated that the most common form of violence is violence. Social, followed by verbal violence, then economic, and agreed with this study that social violence is more prevalent study of awuda (2002) where the study showed that social violence is the most prevalent followed by verbal violence, then health and sexual and then physical, and also agreed with them a study of Badawi (2017) where The study found that social violence is the most prevalent, and that health violence is less prevalent, and in the study of Naseer, Fatima Jadallah and Aisha Husseini (2006) found that economic violence is the most prevalent, followed by psychological, sexual and finally physical violence, while mansour's study (2014) has She explained that moral violence is the most prevalent, followed by social and economic, and in the study of Robert Mbashiri (2003), the Study of Sanon S (2004) and the Rada Study (2004), they found that psychological violence is the most prevalent of other species.

While the Phillips, Mostofian,Puthukudy (2015) and Stark,Warner,Lehamann (2013) agreed that the most common form of violence is sexual violence, while a study of Fayez (2006) showed that psychological violence is more prevalent followed by physical violence, as well as the study of Yusra Ismail (2006) 1437H) The most common form of violence is psychological violence, then verbal violence, followed by physical, economic, health, and sexual ity.

From previous studies to identify the most common forms of violence from husbands to wives, the results varied, and may be due to the nature of each society in which the study is conducted, and the factors causing violence vary from society to society and from person to person. 


\section{References:-}

1. Abraham, Muhammad Abd al-Nabi. Poverty in rural Egypt, dimensions, features and adaptation methods. Cairo: Cairo University Press.

2. Abu Al-Nasr, Medhat Mohammed. (2006). Contemporary trends in the practice of preventive social service. (First edition). Cairo: Arab Nile Group.

3. Alcied. Abdul Ati. (2014). Family sociology. (First edition). Cairo: University Knowledge House.

4. Al-Fiqi, Mustafa and Ahmed, Mohammed and Hajjaj, Ibrahim. Contemporary social problems. (First edition). Dammam: Al-Mutanabbi Library.

5. Al-Khatib, Salwa Abdel Hamid. Domestic violence against women in Riyadh. An unpublished study of some cases of frequent cases at Riyadh Central Hospital and the Charitable Center for Social Guidance and Family Counseling.

6. Al-Muhaymid, Ali Mohammed Abdul Aziz. Domestic violence against women in Saudi society. A field study on women working in various fields related to the phenomenon of domestic violence against women in Riyadh. Unpublished PhD. Nayef Arab University of Security Sciences. Riyadh.

7. Al-Nuwahi, Abdul Aziz. General practice in social work, the process of solving the problem within the framework of an e-logical format. (6th edition). Cairo: Samir Printing.

8. Al-Yousef, Abdullah al-Rumaih, Saleh and Niazi, Abdul Majid. Domestic violence. An unpublished field study in Saudi Arabia. Riyadh: National Center for Studies and Social Development. Series of research and studies. Number (51).

9. Ayed, Saad al-Shahrani. Social service and the phenomenon of domestic violence. Research presented to the Conference on Family and Contemporary Changes organized by the Saudi Society of Sociology and Social Service. Riyadh.

10. Badawi, Abdul Rahman Abdullah. Violence against women in Saudi society. Journal of the Faculty of Education. Al-Azhar University. Number (173).

11. BosilikaOjikanovic, HenricaAfMjanson, Stanislava Otasevic,(2010).

12. Chokkanathan . S. (2012): Wife Abuse in Tamil Nadu , J- Fam Viol.27 .275 - 285.

13. Factors Associated with Intimate Parmer Violence Against Women is Serbia: Across- Sectional Study, Jepidemiol Community Health.

14. Faweet, W. (1994): Sex Role Beliefs, and Social Isolation Battered-omen. Journal of Family Violence.7, (1). pp. 1-8.

15. Habib, Jamal Shehata and Hanna, Maryam Ibrahim. (2016). Theories and models of professional intervention on different types and levels of professional protection of social service. (First edition). Alexandria: Modern University Office.

16. Hashimi , H. ; Khurshid , M. \& Hassan , I. (2007): Marital Adjustment . Stress and Depression Among Working and nonworking

17. Hijazi, Hoda Mahmoud and Al-Mizer, Hind Aqeel. (2012). Professional practice of social service in dealing with the problem of domestic violence in Saudi Arabia. Research published at the 25th International Conference on Social Service. Helwan University. Cairo.

18. http: //www.biomedcentral .com/1491-2458/10/490.

19. IBM Corp. Released. IBM SPSS Statistics for Windows, Version 22.0. Armonk, NY: IBM Corp, 2013.

20. Ibn Mansoor, Abu fadl Mohammed. (DN). The tongue of the Arabs. (First edition). Beirut: Dar Sader.

21. Ismail, Yusra Mohammed. (1436H). Forms and effects of violence against women. Unpublished master's degree. King Saud University. Riyadh.

22. Journal of Security and Life. Violence against women. A global problem. 20th year. Number (223).

23. Lindsay Stark, Ann Warner, Heidi Lehmann, Neil Boothby and Alastair Ager (2013). Measuring the incidence and reporting of violence against women and girls in Liberia using the 'neighborhood method', Conflict and Health, Bio med Central, 7:20 .

24. Married Women ,Internet Journal of Medical Update, 2 (I). 19-26.

25. Ministry of Economy and Planning. (2016). Goals and policies for the Tenth Development Plan.

26. Naseer, Abdullah and Jadallah, Fatima and Husseini, Aisha. (2006). Forms of violence towards women. A vision through Saudi society. Unpublished study.

27. Outcome and Process, Violence Against Women, January Vo;17. No.4 .

28. Phillips, M, Mostofian, F, \&Jetly, R, Puthukudy, N, \& Madden, K, Bhandari, M. (2015). Madia Coverage of Violence Against Woman in India: a systematic study of a high profile rape case. BMC Women's Health. 15:3 
29. Rada, Cornelia. (2014). Violence against women by male partners and against children within the family: prevalence, associated factors, and intergenerational transmission in Romania, a cross-sectional study, BMC Public Health,(14), 129.

30. Sanon S, Jain D, Sadowski L, \& Hunter W. (2004). Violence against women in India: evidence from rural Maharashtra, Ind

31. Sara Perez \& Lisa A. Goodman,(2011) . Battered Women's Perceptions of Avil and Crionial Court Helpful- ess: The Role of Court

32. SibelKalaca\& Pinar Dundar,( 2010 ). Violence Against Women: The Perspective of Accademic Women, BMC Public Health, 2010, 1471, 2458-

33. Vision Center for Social Studies. Domestic violence between confrontation and cover-up. Series of studies and research (1).

34. World Health Organization " WHO " (2001):World Report on Violence and Health , Available at www.who.int/violenceinjun.prcvention/violcncc/worldrcport. 